\title{
The Geographic Distribution and Characteristics of U.S. Bank Failures, 2007-2010: Do Bank Failures Still Reflect Local Economic Conditions?
}

\author{
Craig P. Aubuchon and David C. Wheelock
}

\begin{abstract}
The financial crisis and recession that began in 2007 brought a sharp increase in the number of bank failures in the United States. This article investigates characteristics of banks that failed and regional patterns in bank failure rates during 2007-10. The article compares the recent experience with that of 1987-92, when the United States last experienced a high number of bank failures. As during the 1987-92 and prior episodes, bank failures during 2007-10 were concentrated in regions of the country that experienced the most serious distress in real estate markets and the largest declines in economic activity. Although most legal restrictions on branch banking were eliminated in the 1990s, the authors find that many banks continue to operate in a small number of markets and are vulnerable to localized economic shocks. (JEL E32, G21, G28, R11)
\end{abstract}

Federal Reserve Bank of St. Louis Review, September/October 2010, 92(5), pp. 395-415.

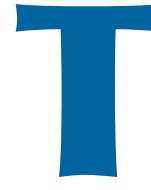

he financial crisis and recession that began in 2007 brought a sharp increase in the number of failures of banks and other financial firms in the United States. The failures and near-failures of very large financial firms, such as Bear Stearns, Lehman Brothers, and American International Group (AIG), grabbed the headlines. However, 206 federally insured banks (commercial banks, savings banks, and savings and loan associations, hereafter "banks")—or 2.4 percent of all banks in operation on December 31, 2006-failed between January 1, 2007, and March 31, 2010. ${ }^{1}$ Failed banks held $\$ 373$ billion of deposits (6.5 percent of total U.S. bank deposits) as of June 30, 2006; Washington Mutual Bank alone accounted for $\$ 211$ billion of deposits in failed banks.

The recent spike in bank failures followed a period of relative tranquility in the U.S. banking industry. Between 1995 and 2007, on average fewer than four banks failed per year. Bank failures were much more common in the 1980s and early 1990s, however, including more than 100 commercial bank failures each year from 1987 to 1992. As percentages of the total number of U.S. banks and volume of bank deposits, the failures of 2007-10 approach the failures of the 1980s and early 1990s (Figures 1 and 2). ${ }^{2}$

The bank failures of the 1980s and early 1990s were concentrated in regions of the country that

\footnotetext{
1 The 206 failures include only banks that were declared insolvent by their primary regulator and were either liquidated or sold, in whole or in part, to another financial institution by the Federal Deposit Insurance Corporation (FDIC). This total does not include banks, bank holding companies, or other firms that received government assistance but remained going concerns, such as the Federal National Mortgage Association (Fannie Mae), Federal Home Loan Mortgage Corporation (Freddie Mac), Citigroup, and GMAC.

2 Figures 1 and 2 include data for both commercial banks and savings institutions but exclude another 747 savings institutions (with $\$ 394$ billion of total assets) that were resolved by the Resolution Trust Corporation between 1989 and 1995 (Curry and Shibut, 2000).
} 


\section{Figure 1}

\section{Bank Failures as a Percent of Total Banks (annually, 1984-2009)}

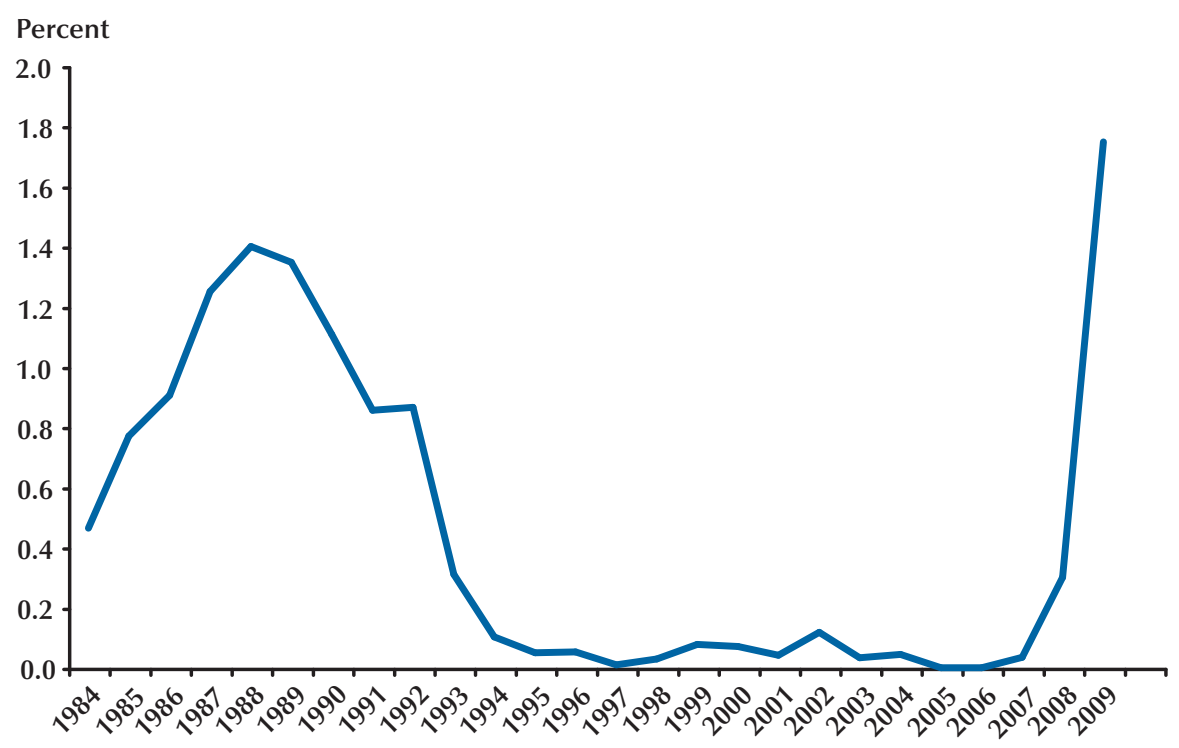

NOTE: Data include all commercial banks and savings institutions except institutions resolved by the Resolution Trust Corporation. SOURCE: FDIC Historical Statistics on Banking and authors' calculations.

experienced unusual economic distress. More than half of all bank failures occurred in Texas alone. Texas and other energy-producing states experienced high numbers of bank failures following a sharp drop in energy prices and household incomes in the mid-1980s. Later, in the early 1990s, New England states had numerous bank failures when state incomes and real estate prices declined. Analysts argued that the concentration of bank failures in regions experiencing high levels of economic distress reflected the geographically fragmented structure of the U.S. banking system in which banks were not permitted to operate branches in more than one state (e.g., Calomiris, 1992; Horvitz, 1992; Federal Deposit Insurance Corporation [FDIC], 1997). Bank failures were especially numerous in Texas and other states that had long restricted branch banking within their borders. Many states eased intrastate branching restrictions during the 1980s, and the RiegleNeal Interstate Banking and Branching Efficiency Act of 1994 subsequently removed federal restric- tions on interstate branching. ${ }^{3}$ Proponents of deregulation argued that the removal of branching restrictions would encourage banks to diversify geographically, which would lessen the impact of local economic shocks on bank performance.

This article examines the characteristics of bank failures during 2007-10 and investigates whether the geographic distribution of failures reflected differences in local economic conditions. The removal of restrictions on branch banking, both within and across state lines, has been followed by substantial consolidation of the U.S. banking industry. Bank failures and mergers have reduced the number of U.S. banks from a postwar peak of 14,496 in 1984 to fewer

\footnotetext{
3 State and federal laws prohibited interstate branching before the Riegle-Neal Act of 1994, and state laws governed branching within states. By the 1980s, a few states permitted entry by out-of-state bank holding companies, usually through the acquisition of an existing bank. However, holding companies were not permitted to merge the operations of their subsidiary banks located in different states. See Spong (2000) for more information about branching and other U.S. bank regulations.
} 


\section{Figure 2}

\section{Percentage of U.S. Bank Deposits in Failed Banks (annually, 1984-2009)}

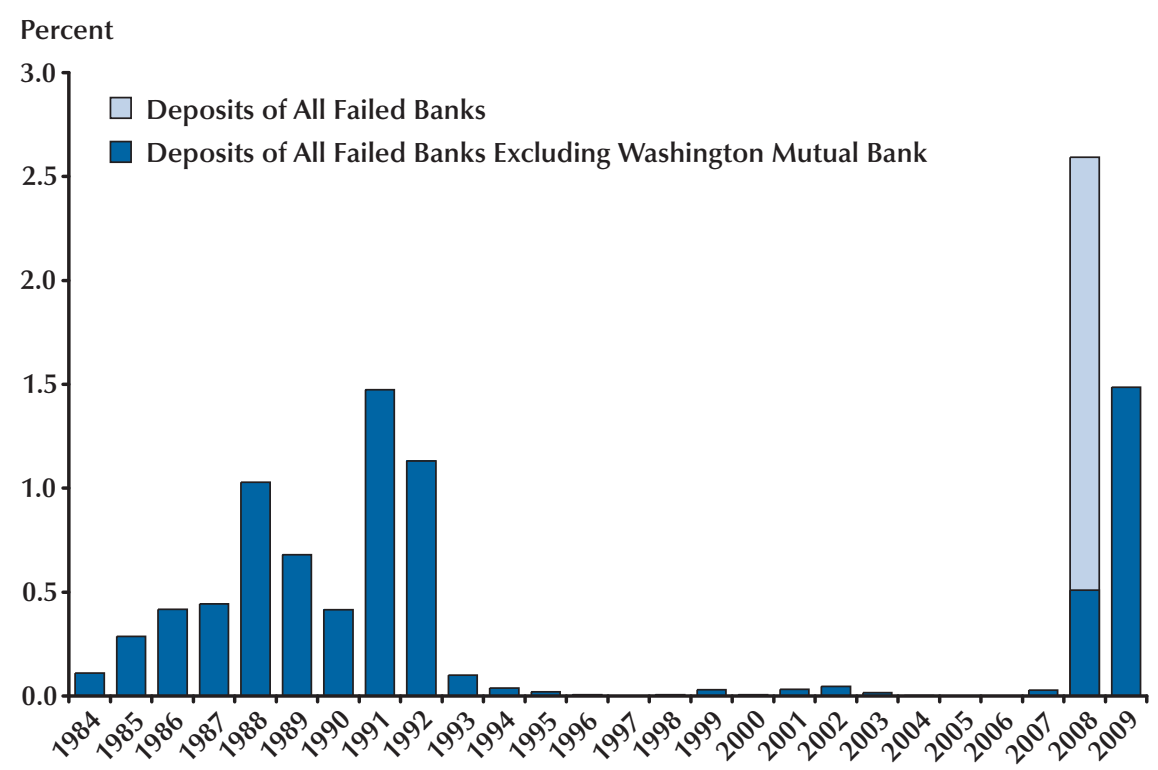

NOTE: Data include all commercial banks and savings institutions except institutions resolved by the Resolution Trust Corporation. SOURCE: FDIC Historical Statistics on Banking and authors' calculations.

than half that number today, and many banks now operate extensive branching networks. Nonetheless, even now most banks have offices in no more than a few states, and many have offices in just a single market. Although banks can reduce their vulnerability to local economic shocks by participating in loans made in other markets, investing in securities, and using other means, the large number of banks that operate predominantly in a single market and serve mainly a local clientele suggests that bank failures are likely to be more numerous in locations experiencing adverse economic shocks. ${ }^{4}$

4 This article does not address why many banks choose not to operate in more than one market. However, for some banks, the costs of managing operations in multiple markets might outweigh the potential benefits of geographic diversification. Emmons, Gilbert, and Yeager (2004) find that small, community banks could reduce their failure risk more by simply increasing their size, regardless of where growth occurs, than by expanding into multiple markets. However, Berger and DeYoung (2006) find that, over time, advances in information-processing technology have reduced the costs of managing far-flung operations, suggesting that banks increasingly will find it advantageous to operate in multiple markets.
We compare the characteristics of failing and non-failing banks during 2007-10, focusing on differences in size and branch operations. We derive state-level bank failure rate measures using branch-level data, which allows us to capture the impact of interstate branching on state-level failure rates. We then investigate the correlation between state bank failure rates and measures of state economic conditions, including measures of distress in housing markets, as well as personal income growth and unemployment rates. Finally, we compare our findings for 2007-10 with evidence on bank failures during the 1980s and early 1990s. We find that, as in earlier periods, during 2007-10 bank failure rates typically were higher in states experiencing more severe economic distress. Thus, even though most branching restrictions were removed more than a decade ago, the regional patterns of bank failures during 2007-10 indicate that many banks remain vulnerable to local economic shocks. 
The next section profiles U.S. bank failures during 2007-10. First, we briefly describe the failures and near-failures of very large financial organizations that succumbed to the collapse of the U.S. housing and mortgage markets. We then focus explicitly on commercial bank and savings institution failures and compare failing and nonfailing banks in terms of size and branching characteristics. We similarly compare failing and non-failing commercial banks during 1987-92. Subsequently, we derive state-level bank failure rates and investigate the correlation between failure rates and measures of the housing boom and subsequent bust, as well as other measures of state economic conditions. Again, we compare the recent experience with that of 1987-92. The final section summarizes our findings and conclusions.

\section{PROFILE OF BANKS THAT FAILED DURING 2007-10}

\section{Large Financial Institution Failures and Near-Failures}

The recent financial crisis and recession was punctuated by several high-profile financial failures and near-failures. This article focuses on the failures of commercial banks and savings institutions. However, we briefly describe the failures and near-failures of some other large financial firms during the financial crisis and recession of 2007-10. The financial crisis was triggered when the housing boom ended and house prices began to fall in many markets. By 2006-07, falling house prices had led to rising home mortgage delinquency rates, which lowered the profits of mortgage lenders, such as Countrywide Financial Corporation, Washington Mutual Corporation, and GMAC, Incorporated. All three of these bank holding companies incurred enormous losses on the mortgage portfolios of their subsidiary banks. Countrywide was acquired by Bank of America in 2008. Washington Mutual was declared insolvent and closed by the Office of Thrift Supervision in September 2008. JPMorgan Chase later acquired the banking operations of Washington Mutual in a transaction facilitated by the FDIC. ${ }^{5}$ GMAC remains a going concern, but to date has received a total of $\$ 17.2$ billion of government support under the Troubled Asset Relief Program (TARP). ${ }^{6}$

Other casualties of the collapse of house prices and rise in mortgage delinquencies included Bear Stearns and Company, Lehman Brothers, Federal National Mortgage Association (Fannie Mae), Federal Home Loan Mortgage Corporation (Freddie Mac), American International Group (AIG), and several large bank holding companies, including Citigroup, Bank of America, Wachovia Corporation, and National City. Bear Stearns and Lehman Brothers were investment banks that invested heavily in mortgage-backed securities for their own accounts and for hedge funds they created and marketed to other investors. The values of mortgage-backed securities fell when subprime mortgage delinquency rates began to rise in 2007 and hedge funds and other investors in subprime mortgages experienced substantial losses. The hedge funds created by Bear Stearns were among the largest and most prominently affected. At first, Bear Stearns covered the losses in its hedge funds, but eventually the funds declared bankruptcy. Bear Stearns itself faced bankruptcy in March 2008 when the firm's creditors refused to renew short-term loans to the firm. The Federal Reserve prevented a bankruptcy filing by creating a special-purpose vehicle (Maiden Lane, LLC) that invested in $\$ 30$ billion of mortgagebacked securities held by Bear Stearns, which facilitated the acquisition of Bear Stearns by JPMorgan Chase. ${ }^{7}$ By contrast, when the creditors of Lehman Brothers were no longer willing to lend to the firm, the Fed determined that Lehman

\footnotetext{
5 See the FDIC press release, "JPMorgan Chase Acquires Banking Operations of Washington Mutual" (www.fdic.gov/news/news/press/2008/pr08085.html).

6 The TARP was established by the Emergency Economic Stabilization Act (HR 1424), which President George W. Bush signed into law on October 3, 2008. The nine largest U.S. bank holding companies were all required to accept government capital under the program. Other banks could apply for capital under the TARP, but only those deemed viable by their primary regulator were eligible to receive capital. Of some 650 banks that received TARP capital, only three subsequently failed before March 31, 2010. These three banks constituted just 1.6 percent of the total number of bank failures between October 1, 2008, and March 31, 2010

7 Details of this transaction are available on the website of the Federal Reserve Bank of New York (www.newyorkfed.org/newsevents/ news/markets/2008/rp080324.html).
} 
lacked sufficient assets to serve as collateral for a rescue loan and the firm was forced to file for bankruptcy in September 2008.

Fannie Mae and Freddie Mac are governmentsponsored enterprises that provide support for the housing market by purchasing home mortgages from loan originators. As government-sponsored corporations, Fannie Mae and Freddie Mac traditionally enjoyed lower borrowing costs than most private firms because many investors believed that the federal government would stand behind the firms' debts even though they were privately held companies. Their implicit federal guarantees allowed Fannie Mae and Freddie Mac to become highly leveraged by borrowing heavily to invest in large portfolios of mortgages and mortgagebacked securities. Both firms grew rapidly during the past decade and became significant purchasers of nonprime mortgage-backed securities (Leonnig, 2008; Greenspan, 2010). The increase in subprime mortgage delinquency rates and decline in the value of subprime mortgage-backed securities quickly eroded the thin capital of both firms, and they were placed under federal government conservatorship in September 2008. ${ }^{8}$ Since then, the firms have required billions of dollars of capital from the federal government to remain going concerns.

AIG is a large financial conglomerate with global operations. The traditional business of AIG is insurance-automobile, life, and so on. AIG also owns a federally chartered savings bank (AIG Bank, FSB). AIG's unregulated activities, notably the underwriting of credit default insurance, produced substantial losses when the housing market slumped badly in 2007-08. These unregulated operations had grown so large that government officials feared that AIG's sudden collapse could impose severe losses on other firms and seriously impair the functioning of the entire financial system. To avoid this outcome the U.S. Treasury and Federal Reserve provided AIG with loans and a capital injection in October 2008 when it appeared that the firm would default on its outstanding debts. ${ }^{9}$

${ }^{8}$ See "Statement by Secretary Henry M. Paulson, Jr. on Treasury and Federal Housing Finance Agency Action to Protect Financial Markets and Taxpayers"

(www.ustreas.gov/press/releases/hp1129.htm).
Washington Mutual Bank, a federally chartered savings bank with some $\$ 300$ billion of assets, was declared insolvent by the Office of Thrift Supervision in September 2008 and placed under the receivership of the FDIC. No other bank with more than $\$ 100$ billion of assets was liquidated or sold by the FDIC during 2007-10. However, among other large bank holding companies, both Citigroup and Bank of America received special assistance from the federal government in the form of capital, portfolio guarantees, and liquidity access; and Wachovia and National City were acquired by other bank holding companies when it became clear that neither remained viable on its own. In providing capital and guarantees to Citigroup, Bank of America, and AIG, as well as assistance to facilitate the acquisition of troubled firms such as Bear Stearns, the Federal Reserve and Treasury Department sought to promote stability of the financial system by avoiding possible systemic repercussions should such a large financial firm fail or declare bankruptcy. ${ }^{10}$

\section{Comparison of Failed and Non-Failing Commercial Banks and Savings Institutions}

Next we focus on the characteristics of commercial banks and savings institutions that were declared insolvent by their primary regulator and whose deposits were either liquidated or sold to another institution by the FDIC. With some $\$ 300$ billion of assets and $\$ 189$ billion of deposits when it was closed by the Office of Thrift Supervision, Washington Mutual Bank was by far the largest bank failure in U.S. history. Only five banks had more assets than Washington Mutual when it failed, and Washington Mutual was nearly 10 times larger in terms of total assets than the nextlargest bank to fail between January 2007 and March 2010. ${ }^{11}$

9 See the Board of Governors' October 8, 2008, press release (www.federalreserve.gov/newsevents/press/other/20081008a.htm).

${ }^{10}$ See Bullard, Neely, and Wheelock (2009) for a discussion of systemic risk and the financial crisis of 2008-09.

${ }^{11}$ JPMorgan Chase, Bank of America, Citibank, Wachovia Bank, and Wells Fargo Bank had more total assets than Washington Mutual at the time of its failure. 
Between January 1, 2007, and March 31, 2010, 206 commercial banks and savings institutions (savings banks and savings and loan associations, hereafter "thrifts") were declared insolvent by their primary regulator and either closed or sold, in whole or in part, to another institution. ${ }^{12}$ This total includes Washington Mutual but does not include AIG, Bank of America, Citigroup, Fannie Mae, Freddie Mac, GMAC, and other firms that received special government assistance in the form of loans, guarantees, or capital injections to avoid failure. It also does not include Bear Stearns or Lehman Brothers, which were not depository institutions or bank holding companies, and it does not include Countrywide Financial Corporation, National City Corporation, Wachovia Corporation, and other financially troubled bank or thrift holding companies that were acquired by other banks without government assistance.

Table 1 provides summary information for banks and thrifts that failed (i.e., were closed by bank regulators) between January 2007 and March 2010, along with similar information for nonfailing institutions. The summary information is based on data for individual banks as of June 2006. ${ }^{13}$ We exclude eight banks that were chartered after June 2006 and failed between January 2007 and March 2010. Of the remaining 198 failures, 162 held commercial bank charters, 33 were savings banks, and 3 were savings and loan associations. ${ }^{14}$ The smallest bank that failed held $\$ 11$ million of assets and $\$ 5$ million of deposits (as of June 2006), whereas the largest (Washington Mutual Bank) held $\$ 350$ billion of assets and $\$ 211$ billion of deposits. Washington Mutual operated 2,213 branches in 15 states when it was closed on September 25, 2008 (it had 2,167 branches in 15 states on June 30, 2006).

Most banks that failed between 2007 and 2010 were much smaller than Washington Mutual

\footnotetext{
12 A list of failed banks since 2000 is available from the FDIC (www.fdic.gov/bank/individual/failed/banklist.html).

${ }^{13}$ Our data are from the Summary of Deposits (www2.fdic.gov/sod/index.asp), which provides branch-level information.

${ }^{14}$ Of the 162 commercial banks that failed, 109 were state-chartered non-Federal Reserve member banks, 21 were state-chartered Federal Reserve members, and 32 were national banks.
}

both in total assets and deposits and in numbers of branches and numbers of states with branch offices. The mean total assets and deposits of failing banks other than Washington Mutual were $\$ 1.2$ billion and $\$ 824$ million, respectively. Reflecting the highly skewed distribution of bank assets, median assets and deposits were much smaller, at \$263 million and \$204 million, respectively. By comparison, among non-failing banks, mean total assets and deposits were $\$ 1.2$ billion and $\$ 695$ million, respectively, and median total assets and deposits were \$119 million and \$97 million. ${ }^{15}$ Thus, among failed banks other than Washington Mutual, mean total assets and deposits of failing banks were similar to those of non-failing banks, but median assets and deposits were considerably larger than those of non-failing banks.

Figure 3 shows kernel density plots for the natural $\log (\mathrm{ln})$ of total assets of failing and nonfailing banks during 2007-10, based on data for June 2006. The figure shows that the banks and thrifts that failed during 2007-10 tended to be larger than non-failing institutions over the range of asset sizes most commonly observed (though as noted, five non-failing banks held more total assets than Washington Mutual). By contrast, during the wave of bank failures of the late 1980s and early 1990s, the commercial banks that failed tended to be smaller than non-failing commercial banks (Figure 4). ${ }^{16}$

Figure 5 shows kernel density plots for the natural $\log (\mathrm{ln})$ of total assets for failed commercial banks, failed savings institutions, and non-failing banks (both commercial banks and savings institutions) as of June 2006. As shown, savings institutions that failed between 2007 and 2010 tended to be much larger than both commercial banks that failed and non-failing banks. Thrifts tend to specialize in home mortgage lending, and many grew rapidly during the housing boom. Several

\footnotetext{
${ }^{15}$ Data for non-failing banks include banks that were acquired after June 2006 and banks that survived through March 2010.

${ }^{16}$ As noted previously, our data for 2007-10 include both commercial banks and savings institutions. However, comparable data on savings institution failures are not available for the late 1980s and early 1990s and, hence, the densities shown in Figure 4 for 1987-92 are based exclusively on data for commercial banks.
} 


\section{Table 1}

Descriptive Statistics, Failed Banks January 2007-March 2010 (based on data for 2006:Q2)

\begin{tabular}{|c|c|c|c|c|c|c|}
\hline Type of bank & $\begin{array}{l}\text { Total assets } \\
\text { (\$ thousands) }\end{array}$ & $\begin{array}{l}\text { Total deposits } \\
\text { (\$ thousands) }\end{array}$ & totbr & tot_zipbr & tot_cntybr & tot_stat \\
\hline \multicolumn{7}{|l|}{ Failed banks } \\
\hline $\mathrm{N}$ & 198 & 198 & 198 & 198 & 198 & 198 \\
\hline Min & 11,073 & 5,161 & 1 & 1 & 1 & 1 \\
\hline Max & $350,890,182$ & $210,626,236$ & 2,167 & 1,746 & 82 & 15 \\
\hline Mean & $2,999,689$ & $1,883,978$ & 21.0 & 17.8 & 3.6 & 1.3 \\
\hline Q1 & 100,486 & 80,662 & 1 & 1 & 1 & 1 \\
\hline Median & 265,800 & 210,198 & 4 & 3 & 2 & 1 \\
\hline Q3 & 693,429 & 579,578 & 8 & 7 & 3 & 1 \\
\hline SD & $25,079,179$ & $15,054,713$ & 155.8 & 126.0 & 7.8 & 1.2 \\
\hline
\end{tabular}

Failed banks

(excluding Washington Mutual)

$\mathrm{N}$

Min

Max

Mean

Q1

Median

Q3

SD
197

11,073

$22,962,845$

$1,233,748$

100,486

262,721

690,828

Non-failing banks

$\mathrm{N}$

Min

Max

Mean

Q1

Median

Q3

$\mathrm{SD}$
$3,398,678$
8,307

1,205

$1,160,260,442$

$1,244,305$

56,366

119,175

281,289

$21,858,396$
197

1

301

10.1

824,373

80,662

204,070

575,772

$2,087,900$

8,307

0

$563,906,844$

694,999

46,301

97,474

226,378

$9,775,712$
1

4

8

28.0

8,307

1

5,781

10.8

1

3

6

99.3
197

1

267

9.0

1

3

7

25.2

8,307

1

4,124

8.3

1

2

5

70.3
$197 \quad 197$

11

$52 \quad 6$

$3.2 \quad 1.2$

$1 \quad 1$

21

31

$\begin{array}{ll}5.5 & 0.7\end{array}$

NOTE: N, number of observations; Q1 and Q3, first and third quartiles, respectively; SD, standard deviation; totbr, total number of branches; tot_zipbr, total number of unique zip codes; tot_cntybr, total number of counties; tot_statebr, total number of states in which a bank operates at least one branch. 
Figure 3

Size Distribution of Banks (2006:Q2)

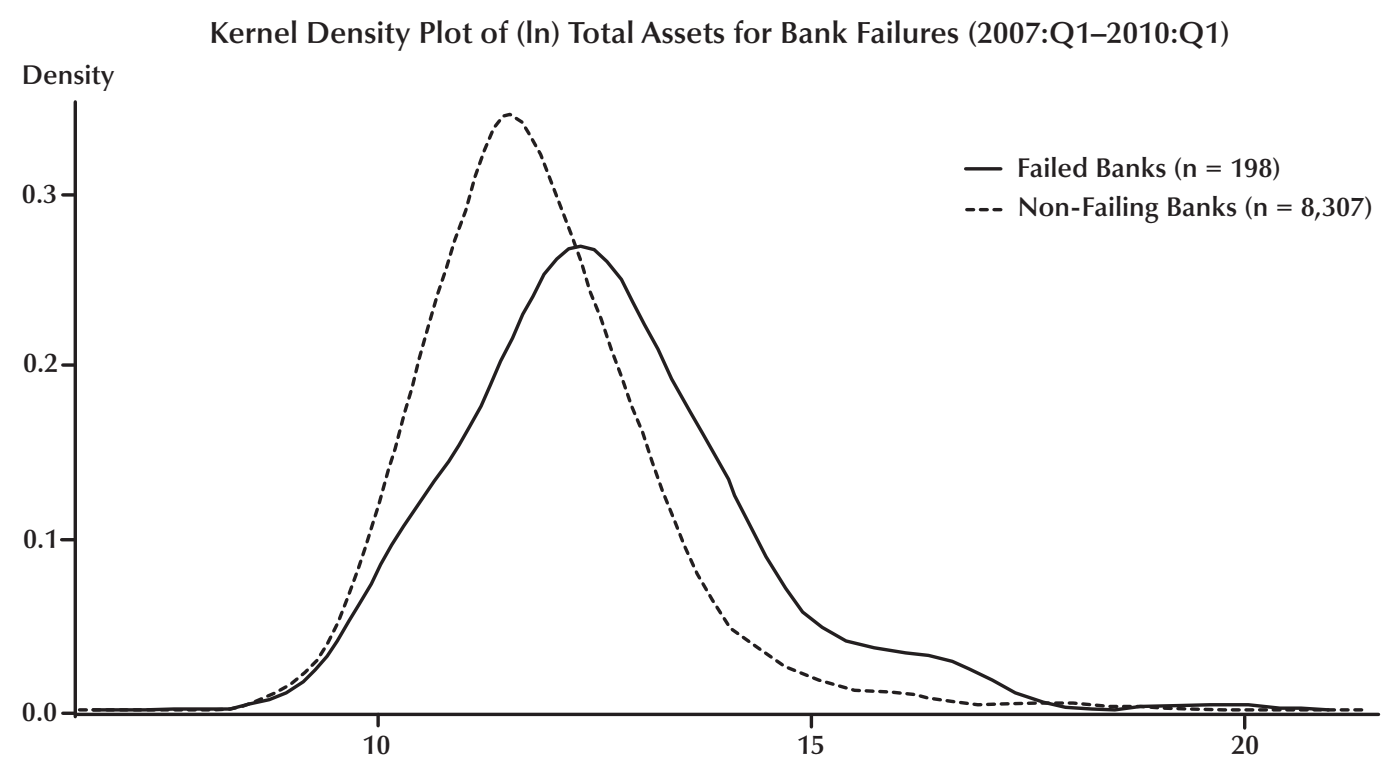

(In) Total Assets

\section{Figure 4}

\section{Size Distribution of Commercial Banks (1986:Q2)}

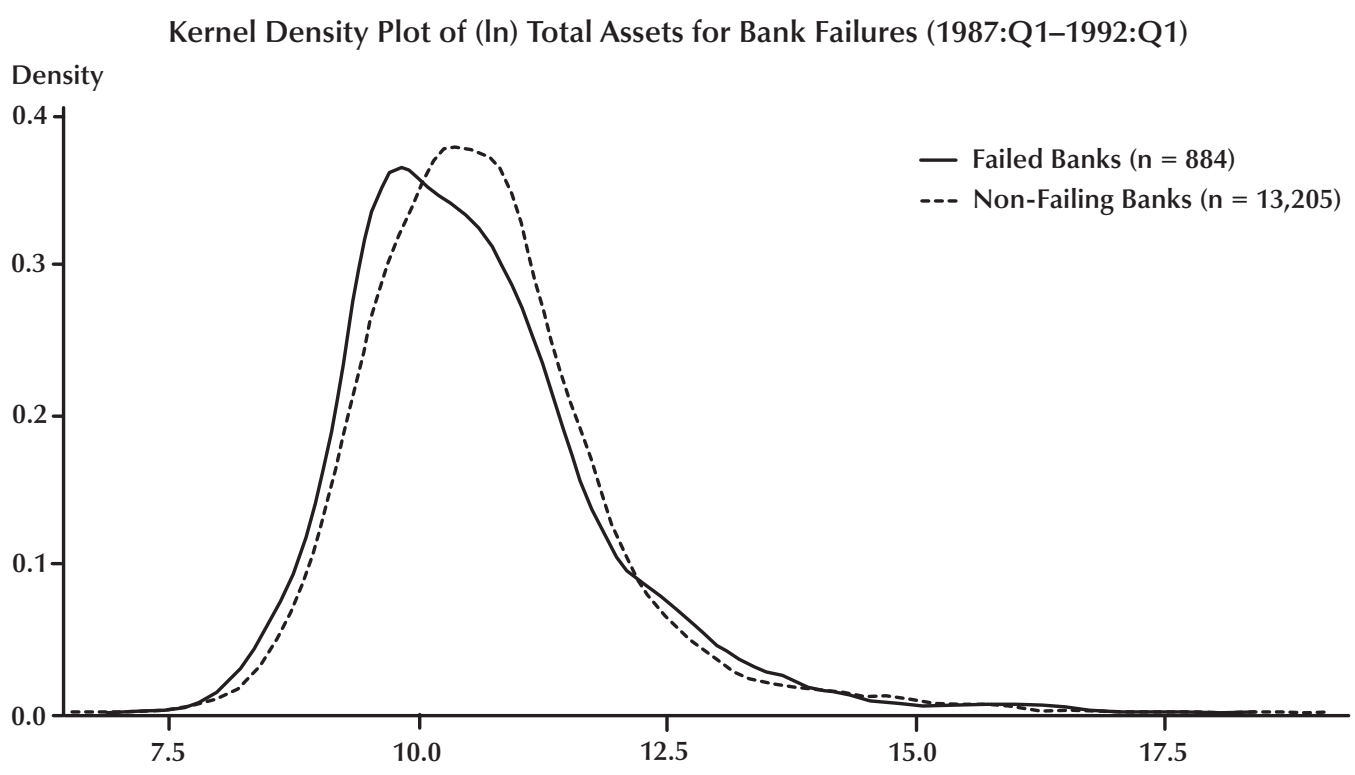

(In) Total Assets

NOTE: Densities shown are based exclusively on data for commercial banks. 


\section{Figure 5}

\section{Size Distribution of Commercial Banks (2006:Q2)}

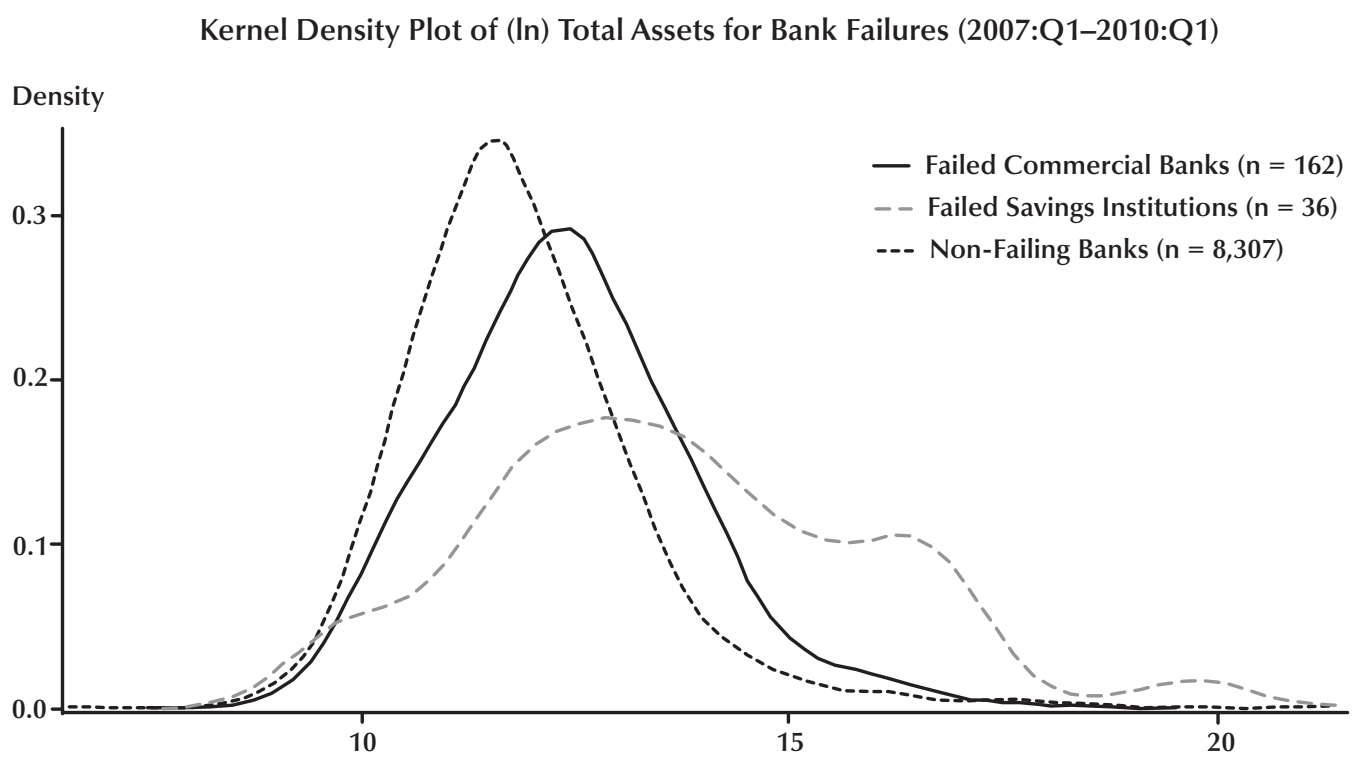

(In) Total Assets

large thrifts failed when house prices began to fall and mortgage delinquencies rose.

Table 2 lists the 20 largest failed banks in terms of total assets on June 30, 2006. Of the 20 largest failures, 11, including Washington Mutual Bank, were savings institutions. Of the 36 thrifts that failed during 2007-10, 16 (44 percent) had at least $\$ 1$ billion of assets. By contrast, of the 162 commercial banks that failed, only one (Colonial Bank of Montgomery, Alabama) had more than $\$ 10$ billion of assets, and only 22 (14 percent) had more than $\$ 1$ billion of assets. As noted previously, in a few cases the federal government intervened to ensure that a very large, systemically significant commercial bank would not fail. In addition, several thrifts experienced large declines in total assets in the months between June 2006 and their failure dates.

Next we compare failed and non-failing banks on the basis of the number and location of branch offices. The sharp increase in bank failures during the 1980s and the apparent vulnerability of banks to sudden changes in local economic conditions led many states and, ultimately, the federal government to relax restrictions on branch banking. ${ }^{17}$ Branching proponents argue that geographic restrictions on bank location contribute to banking system instability by making it more costly for banks to diversify or exploit economies of scale. ${ }^{18}$ Although banks can achieve geographic diversification through loan participations, brokered deposits, and other techniques, most banks served mainly a local loan and deposit market before branching restrictions were relaxed.

Branching deregulation promoted a substantial consolidation of the U.S. banking industry and the advent of banks with interstate branches. The largest U.S. banks operate thousands of branch offices across several states. For example, as of June 30, 2009, Bank of America had 6,173 branches in 35 states and JPMorgan Chase operated 5,229

${ }^{17}$ Kroszner and Strahan (1999) and Garrett, Wagner, and Wheelock (2005) examine the determinants of state branching deregulation.

${ }^{18}$ See Wheelock and Wilson (2009) and references therein for recent estimates of scale economies in banking. 


\section{Table 2}

\section{Largest 20 Bank Failures January 2007-March 2010}

\begin{tabular}{|c|c|c|c|c|c|c|c|}
\hline Bank name & City & State & $\begin{array}{c}\text { Total assets } \\
\text { (\$ Thousands) }\end{array}$ & $\begin{array}{l}\text { Total deposits } \\
\text { (\$ Thousands) }\end{array}$ & $\begin{array}{c}\text { Total } \\
\text { branches }\end{array}$ & $\begin{array}{c}\text { Total states } \\
\text { with a branch }\end{array}$ & $\begin{array}{c}\text { Entity } \\
\text { type }\end{array}$ \\
\hline Washington Mutual Bank, FSB & Henderson & Nevada & $350,890,182$ & $210,626,236$ & 2,167 & 15 & $\mathrm{~S}$ \\
\hline Colonial Bank, National Association & Montgomery & Alabama & $22,962,845$ & $16,242,689$ & 301 & 5 & $\mathrm{C}$ \\
\hline IndyMac Bank, FSB & Pasadena & California & $22,743,262$ & $9,575,579$ & 26 & 1 & $\mathrm{~S}$ \\
\hline Downey Savings and Loan Association & Newport Beach & California & $17,464,594$ & $11,936,431$ & 172 & 2 & S \\
\hline Guaranty Bank & Austin & Texas & $16,920,624$ & $9,362,598$ & 152 & 2 & $\mathrm{~S}$ \\
\hline Ohio Savings Bank, FSB* & Cleveland & Ohio & $16,605,531$ & $11,188,582$ & 56 & 3 & $\mathrm{~S}$ \\
\hline BankUnited, FSB & Coral Gables & Florida & $12,866,372$ & $6,014,740$ & 73 & 1 & $\mathrm{~S}$ \\
\hline First Federal Bank of California, FSB & Santa Monica & California & $10,256,842$ & $5,542,113$ & 32 & 1 & $\mathrm{~S}$ \\
\hline Corus Bank, National Association & Chicago & Illinois & $9,369,988$ & $8,320,397$ & 14 & 1 & $\mathrm{C}$ \\
\hline United Commercial Bank & San Francisco & California & $8,280,022$ & $5,497,301$ & 47 & 4 & $\mathrm{C}$ \\
\hline Irwin Union Bank and Trust Co. & Columbus & Indiana & $6,020,353$ & $3,412,938$ & 24 & 4 & $\mathrm{C}$ \\
\hline California National Bank & Los Angeles & California & $5,518,094$ & $4,573,222$ & 66 & 1 & $\mathrm{C}$ \\
\hline Franklin Bank & Houston & Texas & $5,091,755$ & $2,533,644$ & 36 & 1 & $\mathrm{~S}$ \\
\hline PFF Bank and Trust & Pomona & California & $4,382,916$ & $3,140,649$ & 30 & 1 & $\mathrm{~S}$ \\
\hline NetBank & Alpharetta & Georgia & $4,151,957$ & $2,726,334$ & 1 & 1 & $\mathrm{~S}$ \\
\hline Park National Bank & Chicago & Illinois & $3,573,050$ & $2,931,298$ & 26 & 1 & $\mathrm{C}$ \\
\hline Imperial Capital Bank & La Jolla & California & $3,202,090$ & $1,834,731$ & 9 & 2 & $\mathrm{C}$ \\
\hline La Jolla Bank, FSB & La Jolla & California & $2,773,055$ & $1,532,533$ & 10 & 2 & $\mathrm{~S}$ \\
\hline San Diego National Bank & San Diego & California & $2,356,452$ & $2,055,567$ & 21 & 1 & $\mathrm{C}$ \\
\hline Orion Bank & Naples & Florida & $2,080,071$ & $1,511,496$ & 17 & 1 & $\mathrm{C}$ \\
\hline
\end{tabular}

NOTE: Data are from the June 30, 2006, FDIC Summary of Deposits. S, savings institution; C, commercial bank. *On the date of its failure, Ohio Savings Bank was known as Amtrust. 
branches in 26 states. To the extent that branching has facilitated geographic diversification or scale economies, the U.S. banking system should be less vulnerable to local economic shocks than in the past. ${ }^{19}$ Although the recent downturn in U.S. house prices and economic recession affected most of the country, the extent to which house prices and personal incomes fell varied widely across state and local markets. Hence, branching may have afforded banks some protection against downturns in local real estate markets and economic activity.

The opportunity to operate branches in different banking markets clearly does not insulate banks from local economic downturns if they choose not to diversify across markets. Heavy investment in nonprime mortgages and mortgagebacked securities produced significant losses for many large banks with extensive branching networks, such as Washington Mutual. Most banks that failed during 2007-10 operated far fewer offices than Washington Mutual. As shown in Table 1, the median number of branches operated by banks that failed during 2007-10, other than Washington Mutual, was four. Further, most banks that failed had branches over only a limited geographic area: The median failed bank operated branches in just three zip codes across two counties in a single state. A lack of widespread branching is not, however, a distinguishing characteristic of banks that failed. The median non-failing bank operated only three branches located in two zip codes in a single county in a single state.

\section{STATE BANK FAILURE RATES}

The advent of interstate branch banking has made it more difficult to discern the relationship between changes in local economic conditions and bank performance. However, as noted previously, most banks continue to operate in a limited number of banking markets in a single state.

\footnotetext{
${ }^{19}$ However, as discussed in more detail below, branching regulations and other restrictions on market entry may have enhanced the charter values of existing banks and thereby encouraged them to assume less risk than banks in perfectly competitive markets. Hence, the relationship between branching restrictions and bank failures is ultimately an empirical question.
}

Hence, it remains interesting to consider the extent to which bank failures are associated with changes in local or regional economic conditions. We identified the home state of every bank that failed between January 1, 2007, and March 31, 2010, and calculated state-level failure rates as (i) the ratio of the number of banks headquartered in a state that failed to the total number of banks headquartered in that state as of June 30, 2006; and (ii) the ratio of the deposits held by failed banks in a state to the total amount of deposits held by all banks in that state as of June 30, 2006. We used annual branch-level data on total deposits for all U.S. banks to calculate the deposits-based failure rate. ${ }^{20}$ This measure captures the influence on a state's failure rate of the deposits in branches of banks that are headquartered in another state.

Figure 6 shows the distribution of the failure rate (ratio of failed to total banks) across U.S. states. Georgia had the highest number of failures, with 36 (of 346 banks), but Nevada experienced the highest failure rate, with 5 of 28 banks failing. Arizona, California, and Oregon also had failure rates of at least 8.5 percent. Fifteen states had no bank failures during this period, including six states in the Northeast (Delaware, Maine, Massachusetts, New Hampshire, Rhode Island, and Vermont), four southeastern states (Kentucky, Mississippi, South Carolina, and Tennessee), and two Great Plains states (Montana and North Dakota).

Figure 7 shows the distribution of the depositsbased failure rate measure across states. The impact of interstate branching and differences in the sizes of failed banks across states is apparent. For example, only two small banks chartered in New York failed, giving the state a bank failure rate of only 0.99 percent. However, because of the failure of Washington Mutual Bank, which operated 209 branches with some \$15 billion of deposits in New York, 1.95 percent of the state's bank deposits were in banks that failed. California, Nevada, and Washington are other states for which

\footnotetext{
${ }^{20}$ Our branch-level data on deposits are from the Summary of Deposits database, which is maintained by the FDIC (www2.fdic.gov/sod/index.asp). The appendix presents definitions and source information for all variables and data used in this article.
} 


\section{Figure 6}

\section{Bank Failure Rates (2007-10)}

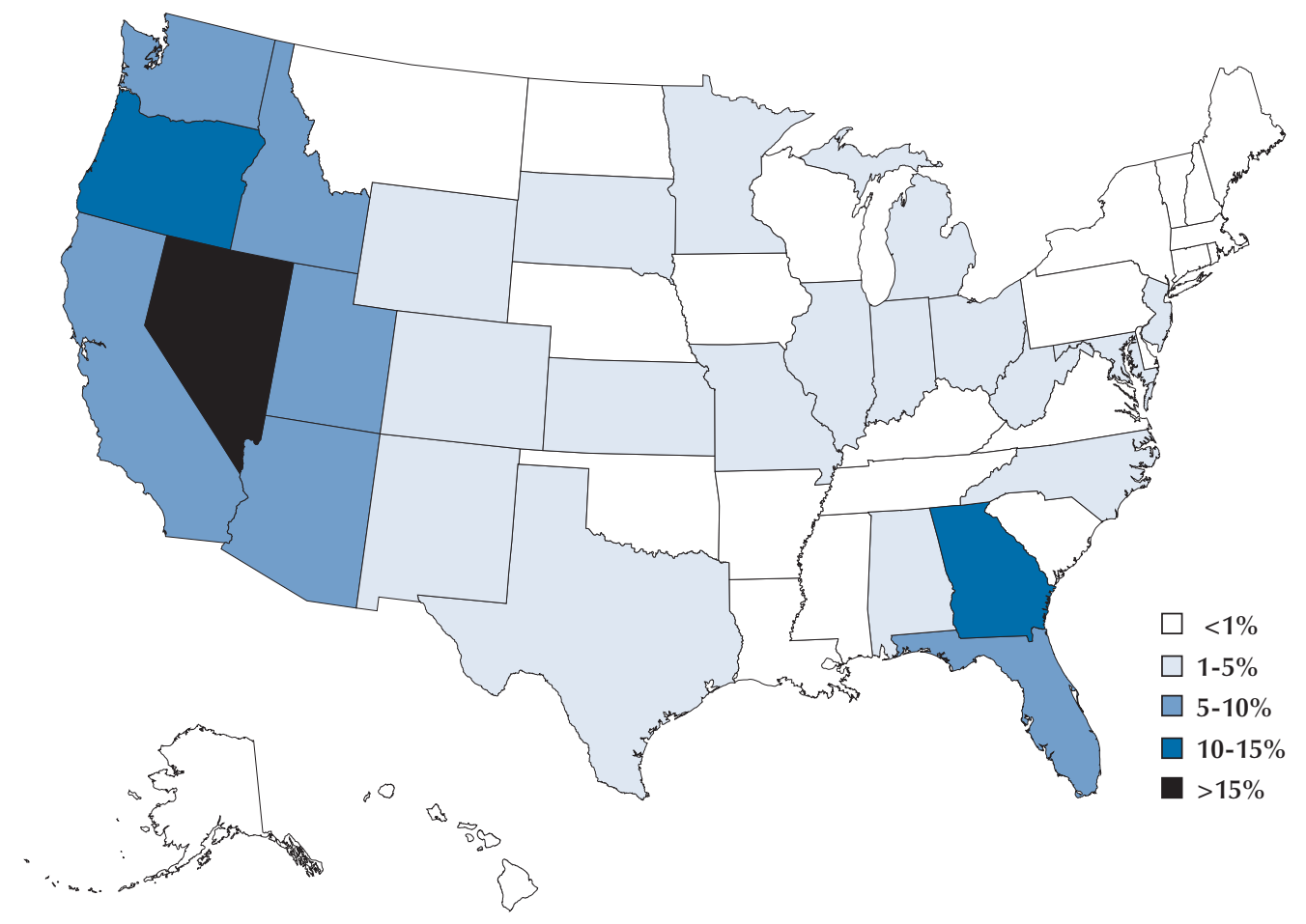

the failure of Washington Mutual caused the percentage of deposits in failed banks to exceed the state's bank failure rate. Similarly, the failure of a single large bank (Corus Bank National Association) caused Illinois to have a relatively high percentage of deposits in failed banks compared with the state's bank failure rate. By contrast, Georgia had a relatively low percentage of deposits in failed banks, despite a high failure rate based on the number of failed banks, because most of the banks that failed in Georgia were small.

\section{STATE BANK FAILURE RATES AND ECONOMIC CONDITIONS}

The recent decline in U.S. house prices was the largest and most widespread since the Great Depression. Mortgage delinquency rates rose throughout the United States and were a proxi- mate cause of the financial crisis and recession. The decline in U.S. house prices was particularly problematic for savings institutions-entities that historically have focused on residential mortgage lending. However, many commercial banks have increased their real estate lending in recent years because of increased competition in commercial lending and apparent profit opportunities in real estate lending. ${ }^{21}$ For example, between December 31, 1996, and December 31, 2006, real estate loans (both residential and commercial) rose from 39.5 percent to 57.4 percent of total U.S.

\footnotetext{
${ }^{21}$ Small, community banks traditionally have dominated small business lending, where close proximity and personal relationships have been important for ascertaining the creditworthiness of potential borrowers. However, advances in information-processing technology have increased competition in local bank markets by making quantifiable information about potential borrowers more readily available (Petersen and Rajan, 2002). In addition, the easing of branching restrictions and other entry barriers increased competition in local banking markets.
} 


\section{Figure 7}

\section{Percentage of Deposits in Failed Banks (2007-10)}

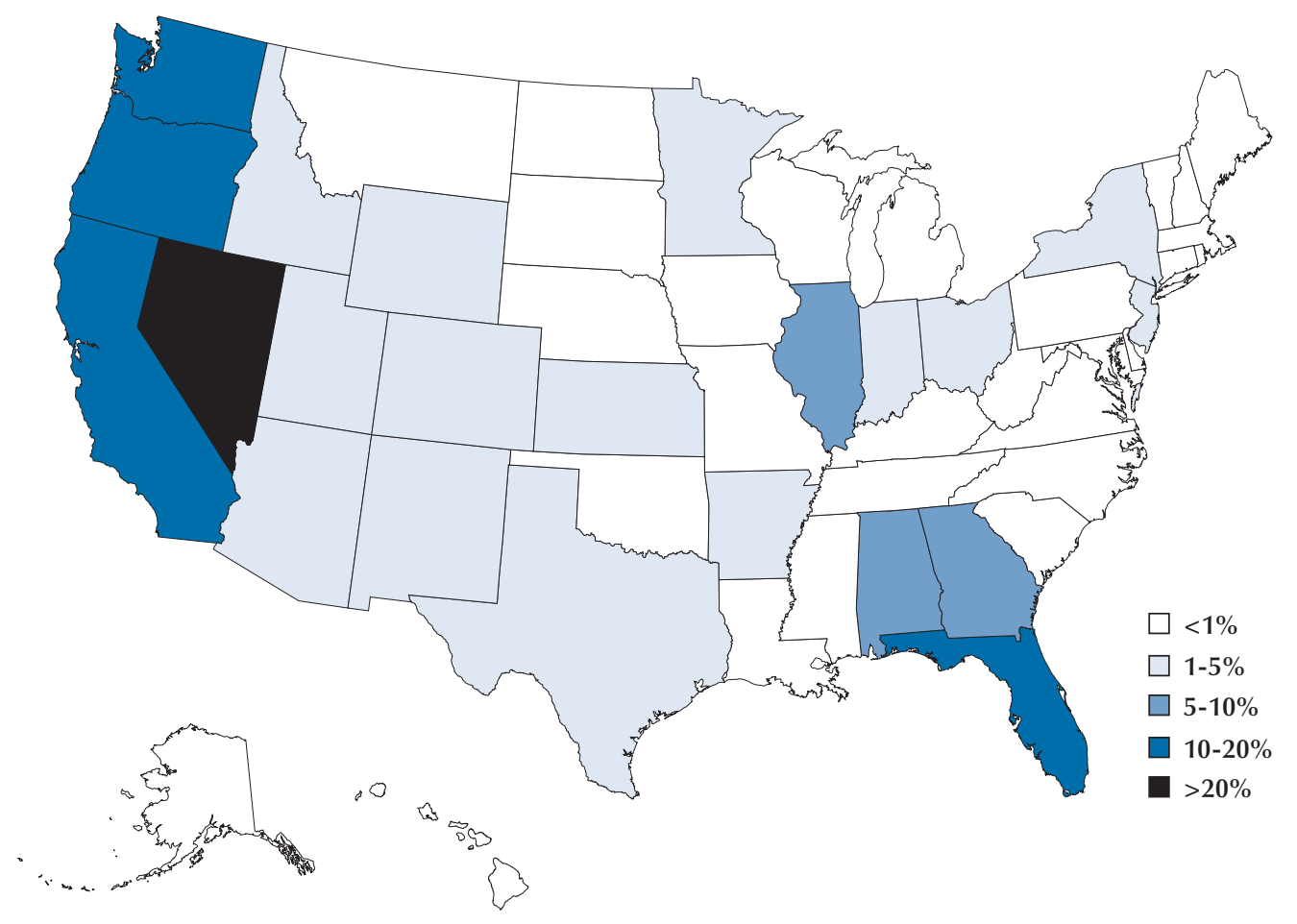

commercial bank loans while commercial and industrial loans fell from 25.2 percent to 19.0 percent of total loans. ${ }^{22}$

Although house prices fell throughout the United States, distress in housing and mortgage markets was especially acute in states that had experienced large increases in house prices in preceding years. Correlations reported in Table 3 show that states with large increases in house prices between 2003:Q3 and 2007:Q1, as measured by the state-level Federal Housing Finance Agency (FHFA) House Price Index, also tended to have (i) relatively high percentages of subprime home mortgages as of 2006:Q4, (ii) large increases in subprime mortgages as a percentage of all residential mortgages between 2003 and 2006, and (iii) rapid growth in total real estate loans (resi-

\footnotetext{
22 These calculations are based on data from the FDIC Statistics on Banking for all U.S. commercial banks (www2.fdic.gov/SDI/SOB/).
}

dential and commercial) between 2003 and 2006. ${ }^{23}$ Further, these states tended to have the largest declines in house prices between 2007:Q1 and 2009:Q4.

Table 4 reports correlations of the number of bank failures and the two failure rate measures with various measures of state-level economic conditions. As shown, the two failure rate measures are highly correlated with the percentage change in house prices during both the period of rising house prices (2003:Q3-2007:Q1) and the period of falling prices (2007:Q1-2009:Q4). State

\footnotetext{
${ }^{23}$ State-level data on real estate loans attribute all of a bank's loans to the state in which the bank is headquartered. Branch-level loan data are not available. We report data for all insured commercial banks, trust companies, and savings institutions as provided by the FDIC. State-level delinquency rates measure the percent of all mortgages past due (not including mortgages in the foreclosure process), as reported by the Mortgage Bankers Association National Delinquency Survey. Similarly, data for the number of conventional subprime loans are from the Mortgage Bankers Association. See the appendix for additional information.
} 


\section{Table 3}

\section{Correlation of State-Level Economic Variables}

\section{Variable}

(1)

(2)

(3)

(4)

(5)

(6)

(7)

(8)

(9)

(10)

(1) Percentage change in the FHFA House Price Index (2003:Q3-2007:Q4)

(2) Percentage change in the FHFA House Price $-0.68$ $(0.00)$ Index (2007:Q1-2009:Q4)

(3) Percentage change in the level of gross loans secured by real estate for all insured commercial

$0.19-0.31$

$(0.18) \quad(0.03)$ banks, trusts, and savings institutions (2002-06), annual data-year end

(4) Ratio of subprime mortgages to all mortgages (2006:Q4)

(5) Change in the ratio of subprime mortgages to all mortgages (2003:Q3-2006:Q4)

(6) Change in the mortgage delinquency rate (all loans) (2009:Q4-2007:Q1)

(7) Change in the unemployment rate (2009:Q4-2006:Q4)

(8) Percent change in real per capita income (2005 \$) (2006-09), annual data

$\begin{array}{ccccccc}0.20 & -0.59 & 0.11 & 1.00 & & & \\ (0.16) & (0.00) & (0.43) & & & & \\ 0.31 & -0.53 & 0.20 & 0.69 & 1.00 & & \\ (0.03) & (0.00) & (0.16) & (0.00) & & & \\ 0.46 & -0.83 & 0.27 & 0.75 & 0.65 & 1.00 & \\ (0.00) & (0.00) & (0.06) & (0.00) & (0.00) & & \\ 0.31 & -0.63 & 0.14 & 0.58 & 0.52 & 0.77 & 1.00\end{array}$

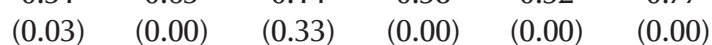

$\begin{array}{lllllll}-0.19 & 0.56 & -0.15 & -0.57 & -0.49 & -0.62 & -0.61\end{array}$

$\begin{array}{lllllll}(0.18) & (0.00) & (0.31) & (0.00) & (0.00) & (0.00) & (0.00)\end{array}$

(9) Percent change in nominal gross state product (2006-08), annual data

$\begin{array}{ccc}-0.13 & 0.54 & 0.16 \\ (0.37) & (0.00) & (0.27)\end{array}$

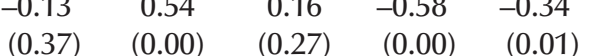

(10) Change in the ratio of business bankruptcies to all establishments (2007-09)

$\begin{array}{ccc}0.15 & -0.15 & 0.06 \\ (0.29) & (0.23) & (0.68)\end{array}$

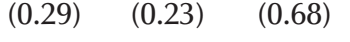

$(0.00) \quad(0.00)$

(11) Branching Restriction Indicator (2006),

0 (no restriction) to 4 (highest restrictions)

$\begin{array}{ccc}(0.46) & (0.33) & (0.32)\end{array}$

$(0.47)-(0.51)$

$0.18 \quad 0.19$

$\begin{array}{cc}-0.29 & -0.25 \\ (0.04) & (0.08)\end{array}$

NOTE: Numbers in parentheses represent $p$ values indicating the statistical significance of the correlation coefficients. 


\section{Table 4}

\section{Correlation of Bank Failures (Rates) and Local Economic Conditions (2007-10)}

\begin{tabular}{|c|c|c|c|}
\hline \multirow[b]{2}{*}{ Variable } & \multicolumn{3}{|c|}{ Failure measure } \\
\hline & nfail_2010 & failrt_06 & dep_failrt06 \\
\hline House Price Index percent change (2003:Q3-2007:Q1) & $\begin{array}{c}0.09 \\
(0.53)\end{array}$ & $\begin{array}{c}0.50 \\
(0.00)\end{array}$ & $\begin{array}{c}0.41 \\
(0.00)\end{array}$ \\
\hline House Price Index percent change (2007:Q1-2009:Q4) & $\begin{array}{l}-0.37 \\
(0.01)\end{array}$ & $\begin{array}{l}-0.68 \\
(0.00)\end{array}$ & $\begin{array}{l}-0.61 \\
(0.00)\end{array}$ \\
\hline $\begin{array}{l}\text { Percent change in gross loans secured by real estate (2002-06) } \\
\text { (commercial and savings banks) }\end{array}$ & $\begin{array}{l}-0.02 \\
(0.91)\end{array}$ & $\begin{array}{c}0.48 \\
(0.00)\end{array}$ & $\begin{array}{c}0.72 \\
(0.00)\end{array}$ \\
\hline Percent of subprime to all mortgages (2006:Q4) & $\begin{array}{c}0.24 \\
(0.09)\end{array}$ & $\begin{array}{c}0.40 \\
(0.00)\end{array}$ & $\begin{array}{c}0.40 \\
(0.00)\end{array}$ \\
\hline Increase in percent of subprime mortgages (2003:Q3-2006:Q4) & $\begin{array}{c}0.28 \\
(0.05)\end{array}$ & $\begin{array}{c}0.47 \\
(0.00)\end{array}$ & $\begin{array}{c}0.40 \\
(0.00)\end{array}$ \\
\hline Change in mortgage delinquency rate (2009:Q4-2007:Q1) & $\begin{array}{c}0.44 \\
(0.00)\end{array}$ & $\begin{array}{c}0.65 \\
(0.00)\end{array}$ & $\begin{array}{c}0.60 \\
(0.00)\end{array}$ \\
\hline Percent change in real per capita income (2006-09) & $\begin{array}{c}-0.40 \\
(0.00)\end{array}$ & $\begin{array}{c}-0.58 \\
(0.00)\end{array}$ & $\begin{array}{c}-0.41 \\
(0.00)\end{array}$ \\
\hline Percent change in gross state product (2006-08) & $\begin{array}{c}-0.23 \\
(0.11)\end{array}$ & $\begin{array}{c}-0.18 \\
(0.20)\end{array}$ & $\begin{array}{c}-0.11 \\
(0.46)\end{array}$ \\
\hline Change in bankruptcy ratio (2007-09) & $\begin{array}{c}0.01 \\
(0.95)\end{array}$ & $\begin{array}{c}0.07 \\
(0.65)\end{array}$ & $\begin{array}{c}0.07 \\
(0.61)\end{array}$ \\
\hline Change in unemployment rate (2009:Q4-2006:Q4) & $\begin{array}{c}0.40 \\
(0.00)\end{array}$ & $\begin{array}{c}0.51 \\
(0.00)\end{array}$ & $\begin{array}{c}0.48 \\
(0.00)\end{array}$ \\
\hline Branching restriction (2006) & $\begin{array}{c}0.10 \\
(0.49)\end{array}$ & $\begin{array}{c}0.15 \\
(0.30)\end{array}$ & $\begin{array}{c}0.16 \\
(0.27)\end{array}$ \\
\hline
\end{tabular}

NOTE: Numbers in parentheses represent $p$ values indicating the statistical significance of the correlation coefficients. Failure measure definitions: nfail_2010, number of bank failures (2007-2010:Q1); failrt_06, number of bank failures (2007-10) divided by total banks in 2006:Q2; dep_failrt06, ratio of deposits of failed banks (2007-10) to total deposits (2006:Q2) calculated at the branch level.

failure rates are also highly positively correlated with the percentage of subprime mortgages in 2006, the growth in the percentage of subprime mortgages between 2003 and 2006, and the percentage increase in total real estate loans between 2003 and 2006. States that experienced the largest increases in house prices during the boom, or the largest declines during the bust, had the highest bank failure rates, as did those with the most rapid growth in subprime mortgage loans and total real estate loans. Not surprisingly, since the delinquency rates on subprime mortgages are much higher than those on prime loans, state bank failure rates are also highly positively correlated with the increase in residential mortgage loan delinquency rates between 2006 and 2009. ${ }^{24}$
Many states with large declines in house prices also experienced relatively large declines in personal income and gross state product and relatively large increases in unemployment rates. For example, Florida and Arizona were the only states where real per capita personal income fell more than 7 percent between 2006 and 2009; along with Nevada and California, they were the only states where the decline in house prices between 2007 and 2009 exceeded 30 percent.

${ }^{24}$ Distress in commercial real estate markets has frequently been cited as another cause of losses and bank failures during 2007-10 (e.g., Bair, 2010; Wutkowski, 2009). State-level data on commercial real estate market conditions are not available; historically, however, many bank failures have been associated with downturns in commercial real estate markets (FDIC, 1997). 
Similarly, Michigan had the smallest increase in gross state product between 2006 and 2008 and had the fifth-largest decline in house prices, 17 percent, behind Arizona, California, Florida, and Nevada. As shown in Table 4, bank failure rates were higher in states that experienced relatively large declines in real per capita personal income or nominal gross state product between 2006 and 2008 (though the correlations with gross state product are not statistically significant), and relatively large increases in the unemployment rate between 2006:Q4 and 2009:Q4. We found no correlation, however, between bank failure rates and changes in business bankruptcy rates between 2007 and 2009. ${ }^{25}$

Lastly, we investigated the association between market entry restrictions on banks and state bank failure rates. As noted previously, many states relaxed restrictions on branching and began to permit entry by out-of-state bank holding companies during the 1970s and 1980s, and a federal prohibition on interstate branching was removed in 1994. However, several states retained limits on entry, such as caps on the share of a state's deposits that a single bank can hold and requirements that a bank seeking to enter a new market must do so by acquiring an existing bank. Rice and Strahan (2010) find that these types of entry barriers reduce the supply of credit to small business borrowers and increase interest rates on loans by 25 to 45 basis points. Similarly, Favara and Imbs (2009) find that relaxing restrictions on bank entry increases the number and volume of home mortgage loans originated by commercial banks within a state and increases house prices. Several studies find that branching and other entry barriers affect state-level measures of economic performance. For example, Jayaratne and Strahan (1996) find that relaxation of state branching restrictions in the 1970s and 1980s significantly increased state real income growth rates. However, estimates of the impact of deregulation

\footnotetext{
${ }^{25}$ We calculated the business bankruptcy rate as the number of business bankruptcy filings during a year divided by the number of private firms in existence in the fourth quarter of the prior year. Data on bankruptcy filings are from the Administrative Office of the United States Courts. Data on the number of private firms are from the Bureau of Labor Statistics Quarterly Census of Employment and Wages.
}

on growth from studies that account for either the possibility that slowly growing states were more likely to deregulate (Freeman, 2002) or spatial dependence in state growth rates (Garrett, Wagner, and Wheelock, 2007) find considerably smaller effects of deregulation on state income growth. More recently, Acharya, Imbs, and Sturgess (2009) find that branching restrictions limit the scope of banks to pursue efficient diversification, which in turn limits the diversification of investment activity within a state.

The literature concludes that branching and other entry regulations can inhibit efficient diversification by banks and affect the cost and supply of credit for borrowers. To the extent that diversification is limited, entry barriers might make banks more vulnerable to local economic distress, as discussed previously. Entry barriers might also promote instability by protecting inefficient banks from competitive forces. On the other hand, entry barriers might allow incumbent banks to earn higher-than-normal profits, which would tend to encourage conservative practices and thereby keep bank failure rates lower than failure rates in states with low entry barriers. ${ }^{26}$ Hence, the relationship between entry barriers and bank failure rates is an empirical question.

Rice and Strahan (2010) construct an index of bank entry restrictions for each U.S. state, ranging from 0 for no restrictions to a maximum of 4 for states that impose the most restrictions on bank entry. Table 4 reports the correlation of values of this index for December 2006 with state-level bank failure rates for 2007-10. The correlation is positive, indicating that bank failure rates were higher in states that imposed more entry restrictions, but not statistically significant at conventional significance levels. Hence, we find some weak evidence that entry restrictions contributed to the high bank failure rates observed in some states.

\section{COMPARISON WITH 1987-92}

The close association between state bank failure rates and economic conditions during 2007-10

\footnotetext{
${ }^{26}$ Keeley (1990) finds that increased competition reduces bank charter values, which in turn encourages banks to increase asset risk and hold less capital, and ultimately raises the risk of bank failure.
} 


\section{Table 5}

\section{Correlation of Bank Failures (Rates) and Local Economic Conditions (1987-92)}

\begin{tabular}{|c|c|c|c|}
\hline \multirow[b]{2}{*}{ Variable } & \multicolumn{3}{|c|}{ Failure measure } \\
\hline & nfail_1992 & failrt_86 & dep_failrt86 \\
\hline House Price Index percent change (1982:Q3-1987:Q1) & $\begin{array}{l}-0.17 \\
(0.23)\end{array}$ & $\begin{array}{c}0.01 \\
(0.94)\end{array}$ & $\begin{array}{c}0.12 \\
(0.40)\end{array}$ \\
\hline House Price Index percent change (1987:Q1-1992:Q4) & $\begin{array}{l}-0.24 \\
(0.10)\end{array}$ & $\begin{array}{l}-0.38 \\
(0.01)\end{array}$ & $\begin{array}{l}-0.41 \\
(0.00)\end{array}$ \\
\hline $\begin{array}{l}\text { Percent change in gross loans secured by real estate (1982-86) } \\
\text { (commercial banks) }\end{array}$ & $\begin{array}{l}0.12 \\
0.42\end{array}$ & $\begin{array}{l}0.26 \\
0.07\end{array}$ & 0.36 \\
\hline Change in mortgage delinquency rate (1992:Q4-1986:Q4) & $\begin{array}{l}-0.12 \\
(0.40)\end{array}$ & $\begin{array}{l}-0.19 \\
(0.18)\end{array}$ & $\begin{array}{l}-0.12 \\
(0.41)\end{array}$ \\
\hline Percent change in real per capita income (1986-92) & $\begin{array}{l}-0.18 \\
(0.21)\end{array}$ & $\begin{array}{l}-0.54 \\
(0.00)\end{array}$ & $\begin{array}{c}-0.30 \\
(0.03)\end{array}$ \\
\hline Change in unemployment rate (1992:Q4-1986:Q4) & $\begin{array}{c}-0.15 \\
(0.30)\end{array}$ & $\begin{array}{c}-0.04 \\
(0.79)\end{array}$ & $\begin{array}{c}0.04 \\
(0.80)\end{array}$ \\
\hline Percent change in gross state product (1986-1992) & $\begin{array}{c}-0.10 \\
(0.47)\end{array}$ & $\begin{array}{c}-0.37 \\
(0.01)\end{array}$ & $\begin{array}{c}-0.32 \\
(0.02)\end{array}$ \\
\hline Branching restrictions (1986:Q4) & $\begin{array}{c}0.32 \\
(0.03)\end{array}$ & $\begin{array}{c}-0.04 \\
(0.79)\end{array}$ & $\begin{array}{c}-0.00 \\
(0.98)\end{array}$ \\
\hline
\end{tabular}

NOTE: Numbers in parentheses represent $p$ values indicating the statistical significance of the correlation coefficients. Failure measure definitions: nfail_1992, number of commercial bank failures (1987-92); failrt_86: number of commercial bank failures (1987-92), divided by total commercial banks in 1986:Q2; dep_failrt86: ratio of deposits of failed commercial banks (1987-92) to total deposits in all commercial banks (1986:Q2), calculated at the branch level.

is reminiscent of previous episodes when the United States experienced high numbers of bank failures. Most recently, during the 1980s and early 1990s, hundreds of commercial banks and thrifts failed when states experienced large declines in personal income and real estate prices. States with large declines in real estate values tended to sustain longer and deeper declines in economic activity-and more bank distressthan did other states (Wheelock, 2006). A similar phenomenon occurred in the 1920s, when falling commodity prices reduced agricultural incomes and caused the failure of thousands of banks located in farm states and other rural areas. States where farm land values and cultivated acreage had expanded the most during boom years surrounding World War I experienced the highest farm and bank failure rates subsequently (Alston, Grove, and Wheelock, 1994).

Table 5 reports correlations of state bank failure rates for 1987-92 with various measures of economic conditions. More than 200 commercial banks failed in 1987-the most in any year since the Great Depression-and the number of commercial bank failures exceeded 100 in every year through $1992 .{ }^{27} \mathrm{~A}$ total of 884 commercial banks failed between 1987 and 1992. Texas alone had 450 bank failures (among 1,955 active banks in June 1986). Other states with high numbers of failures included Oklahoma (78 failures among 528 banks), Louisiana (57 failures among 300 banks), and Colorado (38 failures among 435 banks). All four states experienced sharp declines in state incomes when energy prices fell. Although all four states also had relatively high bank failure

${ }^{27}$ Here we focus on commercial bank failures because comparable data on thrift failures for 1987-92 are not available. We include both commercial bank and thrift failures in Figures 1 and 2, but the dating of thrift failures during the 1980s is imprecise because many insolvent thrifts remained open when the Federal Savings and Loan Insurance Corporation lacked the resources to resolve them. 
rates, both Alaska (where 5 of 16 banks failed) and Arizona (where 14 of 53 banks failed) had higher failure rates than Texas. Other states with high failure rates included Connecticut (10 of 59 banks failed), New Hampshire (7 of 52 banks failed), and Massachusetts (11 of 102 banks failed). New England states experienced rapid income growth and a real estate boom during the 1980s. The New England economy slowed toward the end of the decade, however, when cuts in federal defense spending and increased competition in the computer industry had a disproportionately large impact on the region (FDIC, 1997). Among U.S. census regions, New England experienced the largest decline in real personal income during the recession of 1990-91.

Although New England states experienced rapid increases in house prices in the 1980s and relatively sharp declines in house prices during 1987-92, other states with high bank failure rates during 1987-92 did not have rapidly rising house prices before the onset of bank failures. As shown in Table 5, state bank failure rates for 1987-92 are not highly correlated with changes in house prices between 1982 and 1987, though they are correlated with changes in house prices during 1987-92: Failure rates typically were higher in states that experienced larger declines in house prices. Bank failure rates are not, however, correlated with changes in mortgage loan delinquency rates between 1986:Q4 and 1992:Q4. Thus, compared with the bank failures of 2007-10, those of 1987-92 were not as strongly associated with distress in housing markets. ${ }^{28}$

As with the bank failures of 2007-10, state bank failure rates for 1987-92 are strongly negatively correlated with growth of per capita personal income and gross state product between 1986 and 1992. States with the largest declines

\footnotetext{
${ }^{28}$ However, commercial real estate market conditions may have played important roles in both periods. Spong and Sullivan (1999, pp. 73 and 74) note that between 1981 and 1986, tax laws allowed investors to use an accelerated depreciation schedule for real property, which tended to inflate commercial property values. The removal of these tax shelters "helped to send the industry into a downward spiral," which was "at the forefront of many of the banking problems of the 1980s and early 1990s." Unfortunately, as noted previously, state-level data on commercial real estate market conditions are not available to examine the correlation of commercial real estate conditions with bank failure rates.
}

in personal income or gross state product tended to have the highest bank failure rates. However, bank failure rates are not closely correlated with state unemployment rates. Finally, we find that the number of bank failures in a state is positively correlated with the presence of restrictions on branch banking. ${ }^{29}$ The four states with the most bank failures-Texas, Oklahoma, Colorado, and Louisiana-either prohibited or severely limited branching within their borders. However, several states with high bank failure rates or high percentages of deposits in failed banks, such as Alaska, Arizona, and most states in New England, permitted statewide branching and their state bank failure rates during 1987-92 are not closely correlated with limits on branching within states. Of course, banks in all states were prohibited from operating branches in more than one state, and this prohibition may have been a more important impediment to diversification and scale than branching restrictions within states. ${ }^{30}$

\section{CONCLUSION}

The removal of legal restrictions on branch banking, first by many states in the 1970s and 1980 s and then by the federal government in the 1990s, led to a substantial consolidation of the U.S. banking industry. By 2009, the number of commercial banks in the United States was less than half what it had been in 1984, when the number of banks reached its postwar peak. Still, because many U.S. banks operate only a few branches in a single or small number of markets, the geographic distribution of bank failures is likely to reflect, to some extent, regional differences in economic conditions. Historically, adverse shocks caused locally high numbers of bank failures, as in Texas and New England in

\footnotetext{
${ }^{29}$ Here we use an index that takes a value of 1 for states that allowed unlimited statewide branching, 2 for states that permitted limited branching, and 3 for states that prohibited branching altogether (as of 1986:Q4).

${ }^{30}$ Meyer and Yeager (2001) and Yeager (2004) find that, in general, the performance of small banks that operate within only one county is more closely related to economic activity measured at the state level than to activity within the county in which the bank is located, suggesting that intrastate branching restrictions do not prevent banks from achieving diversification within state borders.
} 
the late 1980s and early 1990s. Small banks with limited geographic diversification have been especially vulnerable to local economic shocks and have tended to fail in higher numbers than larger banks.

In several respects, the geographic patterns of recent U.S. bank failures have been similar to those of past episodes. During 2007-10, bank failure rates were higher in states with the largest declines in personal income and gross state product and the largest increases in unemployment rates. Failure rates were also higher in states experiencing the largest declines in house prices and the largest increases in home mortgage delinquency rates. Those states also had the largest increases in house prices and subprime mortgages before 2007. On average, the percentages of bank loans and assets devoted to home mortgages and mortgage-backed securities rose during the hous- ing boom, which made banks more vulnerable to the subsequent decline in house prices. Unlike previous episodes, banks that failed during this episode tended to be somewhat larger on average than non-failing banks. In particular, reflecting the important role played by home mortgage distress during 2007-10, several large savings institutions failed.

We find that bank failure rates were only modestly correlated with restrictions on intrastate branch banking or bank entry, both in the recent episode and during the failure wave of 1987-92. However, evidence that bank failure rates during 2007-10 were closely correlated with measures of state economic conditions suggests that the long-standing prohibition of interstate branching, though eliminated more than a decade ago, continues to influence the market structure and geographic distribution of bank failures today.

\section{REFERENCES}

Acharya, Viral V.; Imbs, Jean and Sturgess, Jason. "Finance and Efficiency: Do Bank Branching Regulations Matter?” Research Paper No. 06-36; Swiss Finance Institute Research, revised April 8, 2009.

Alston, Lee J.; Grove, Wayne A. and Wheelock, David C. "Why Do Banks Fail? Lessons from the 1920s." Explorations in Economic History, October 1994, 31(4), pp. 409-31.

Bair, Sheila C. "Remarks by FDIC Chairman Sheila C. Bair to the Commercial Mortgage Securities Association Annual Conference.” Washington, DC, January 20, 2010; www.fdic.gov/news/news/speeches/chairman/spjan2010.html.

Berger, Allen N. and DeYoung, Robert. "Technological Progress and the Geographic Expansion of the Banking Industry.” Journal of Money, Credit, and Banking, September 2006, 38(6), pp. 1483-513.

Bullard, James B.; Neely, Christopher and Wheelock, David C. "Systemic Risk and the Financial Crisis: A Primer." Federal Reserve Bank of St. Louis Review, September/October 2009, 91(5 Part 1), pp. 403-17; http://research.stlouisfed.org/publications/review/09/09/part1/Bullard.pdf.

Calomiris, Charles W. "Do 'Vulnerable’ Economies Need Deposit Insurance? Lessons from U.S. Agriculture in the 1920s,” in Philip E. Brock, ed., If Texas Were Chile: A Primer on Banking Reform. San Francisco: Institute for Contemporary Studies, 1992, pp. 237-314.

Curry, Timothy and Shibut, Lynn. "The Cost of the Savings and Loan Crisis: Truth and Consequences.” FDIC Banking Review, Fall 2000, 13(2), pp. 26-35; www.fdic.gov/bank/analytical/banking/2000dec/brv13n2 2.pdf.

Emmons, William R; Gilbert, R. Alton and Yeager, Timothy J. "Reducing the Risk at Small Community Banks: Is It Size or Geographic Diversification that Matters?” Journal of Financial Services Research, April 2004, 25(2/3), pp. 259-81.

Favara, Giovanni and Imbs, Jean. “Credit Supply and the Price of Housing.” Working paper, Swiss Finance Institute, December 2009; www.fe.unl.pt/contents/html/File/INOVA\%20PDF/Jean Imbs.pdf. 


\section{Aubuchon and Wheelock}

Federal Deposit Insurance Corporation. History of the Eighties: Lessons for the Future. Washington, DC: FDIC, 1997; www.fdic.gov/bank/historical/history/.

Freeman, Donald G. "Did State Bank Branching Deregulation Produce Large Growth Effects?” Economics Letters, May 2002, 75(3), pp. 383-89.

Garrett, Thomas A.; Wagner, Gary A. and Wheelock, David C. "Regional Disparities in the Spatial Correlation of State Income Growth, 1977-2002.” Annals of Regional Science, September 2007, 41(3), pp. 601-18.

Garrett, Thomas A.; Wagner, Gary A. and Wheelock, David C. "A Spatial Analysis of State Banking Regulation." Papers in Regional Science, November 2005, 84(4), pp. 575-95.

Greenspan, Alan. “Testimony of Alan Greenspan before the Financial Crisis Inquiry Commission.” April 7, 2010; http://fcic.gov/hearings/04-07-2010.php.

Horvitz, Paul M. "The Causes of Texas Bank and Thrift Failures," in Philip E. Brock, ed., If Texas Were Chile: A Primer on Banking Reform. San Francisco: Institute for Contemporary Studies, 1992, pp. 131-60.

Jayaratne, Jith and Strahan, Philip E. "The Finance-Growth Nexus: Evidence from Bank Branch Deregulation." Quarterly Journal of Economics, August 1996, 111(3), pp. 639-70.

Keeley, Michael C. "Deposit Insurance, Risk, and Market Power in Banking.” American Economic Review, December 1990, 80(5), pp. 1183-200.

Kroszner, Randall S. and Strahan, Philip E. "What Drives Deregulation? Economics and Politics of the Relaxation of Bank Branching Restrictions.” Quarterly Journal of Economics, November 1999, 114(4), pp. 1437-66.

Leonnig, Carol D. "How HUD Mortgage Policy Fed the Crisis: Subprime Loans Labeled 'Affordable." Washington Post, June 10, 2008; www.washingtonpost.com/wp-dyn/content/article/2008/06/09/AR2008060902626.html.

Meyer, Andrew P. and Yeager, Timothy J. "Are Small Rural Banks Vulnerable to Local Economic Downturns?" Federal Reserve Bank of St. Louis Review, March/April 2001, pp. 25-38; http://research.stlouisfed.org/publications/review/01/03/0103am.pdf.

Peterson, Mitchell A. and Rajan, Raghuram G. "Does Distance Still Matter? The Information Revolution in Small Business Lending.” Journal of Finance, December 2002, 57(6), pp. 2533-70.

Rice, Tara and Strahan, Philip E. “Does Credit Supply Affect Small-Firm Finance?” Journal of Finance, June 2010, 65(3), pp. 861-89.

Spong, Kenneth. Banking Regulation: Its Purposes, Implementation, and Effects. Fifth edition. Kansas City, MO: Federal Reserve Bank of Kansas City, 2000; www.kansascityfed.org/banking/bankingpublications/RegsBook2000.pdf.

Spong, Kenneth and Sullivan, Richard J. "The Outlook for the U.S. Banking Industry: What Does the Experience of the 1980s and 1990s Tell Us?” Federal Reserve Bank of Kansas City Economic Review, Fourth Quarter 1999, pp. 65-83.

Wheelock, David C. "What Happens to Banks When House Prices Fall? U.S. Regional Housing Busts of the 1980s and 1990s.” Federal Reserve Bank of St. Louis Review, September/October 2006, 88(5), pp. 413-29; http://research.stlouisfed.org/publications/review/06/09/Wheelock.pdf.

Wheelock, David C. and Wilson, Paul W. “Are U.S. Banks Too Large?” Working Paper No. 2009-054B, Federal Reserve Bank of St. Louis, December 2009; http://research.stlouisfed.org/wp/2009/2009-054.pdf.

Wutkowski, Karey. “U.S. Bank Failures Pass 100 Mark for 2009.” Reuters Business and Financial News, October 23, 2009; www.reuters.com/article/idUSTRE59M5GT20091024.

Yeager, Timothy J. "The Demise of Community Banks? Local Economic Shocks Are Not to Blame.” Journal of Banking and Finance, September 2004, 29(9), pp. 2135-53. 


\section{APPENDIX}

\section{Variable Definitions and Data Sources}

\begin{tabular}{|c|c|}
\hline Variable & Definition \\
\hline \multicolumn{2}{|l|}{ Bank failure data } \\
\hline nfail_2010 & Number of bank failures (2007-2010:Q1) \\
\hline failrt_06 & $\begin{array}{l}\text { Number of bank failures (2007-10) divided by total } \\
\text { banks in } 2006: Q 2\end{array}$ \\
\hline dep_failrt06 & $\begin{array}{l}\text { Ratio of deposits of failed banks }(2007-10) \text { to total } \\
\text { deposits }(2006: Q 2) \text { calculated at the branch level }\end{array}$ \\
\hline nfail_1992 & Number of commercial bank failures (1987-92) \\
\hline failrt_86 & $\begin{array}{l}\text { Number of commercial bank failures (1987-92) divided } \\
\text { by total commercial banks in 1986:Q2, by state }\end{array}$ \\
\hline dep_failrt86 & $\begin{array}{l}\text { Ratio of deposits of failed commercial banks (1987-92) } \\
\text { to total deposits in all commercial banks }(1986: Q 2)\end{array}$ \\
\hline \multicolumn{2}{|c|}{ Local economic conditions (2007-10) } \\
\hline hpi_chg03_07 & $\begin{array}{l}\text { Percentage change in the FHFA House Price Index } \\
(2003: Q 3-2007: Q 1)\end{array}$ \\
\hline hpi_chg07_09 & $\begin{array}{l}\text { Percentage change in the FHFA House Price Index } \\
(2007: Q 1-2009: Q 4)\end{array}$ \\
\hline loan_chg02_06 & $\begin{array}{l}\text { Percentage change in the level of gross loans secured } \\
\text { by real estate for all insured commercial banks, trusts, } \\
\text { and savings institutions (2002-06), annual data-year end }\end{array}$ \\
\hline subratio06 & Ratio of subprime mortgages to all mortgages (2006:Q4) \\
\hline sub_chg03_06 & $\begin{array}{l}\text { Change in the ratio of subprime mortgages to all } \\
\text { mortgages (2003:Q3-2006:Q4) }\end{array}$ \\
\hline deliq_chg07_09 & $\begin{array}{l}\text { Change in the mortgage delinquency rate (all loans) } \\
\text { (2007:Q1-2009:Q4) }\end{array}$ \\
\hline unemp_chg06_09 & Change in the unemployment rate (2006:Q4-2009:Q4) \\
\hline pci_chg06_09 & $\begin{array}{l}\text { Percent change in real per capita income }(2005 \$) \\
(2006-09) \text {, annual data }\end{array}$ \\
\hline gdp_chg06_08 & $\begin{array}{l}\text { Percent change in nominal gross state product } \\
(2006-08) \text {, annual data }\end{array}$ \\
\hline bbq_chg07_09 & $\begin{array}{l}\text { Change in the ratio of business bankruptcies to all } \\
\text { establishments }(2007-09)\end{array}$ \\
\hline restrict06 & $\begin{array}{l}\text { Branching Restriction Indicator, } 0 \text { (no restriction) } \\
\text { to } 4 \text { (highest restrictions) }\end{array}$ \\
\hline \multicolumn{2}{|c|}{ Local economic conditions (1987-92) } \\
\hline hpi_chg82_87 & $\begin{array}{l}\text { Percentage change in the FHFA House Price Index } \\
(1982: Q 3-1987: Q 1)\end{array}$ \\
\hline hpi_chg87_92 & $\begin{array}{l}\text { Percentage change in the FHFA House Price Index } \\
(1987: Q 1-1992: Q 4)\end{array}$ \\
\hline loan_chg82_86 & $\begin{array}{l}\text { Percentage change in the level of gross loans secured } \\
\text { by real estate for all insured commercial banks and } \\
\text { trusts (1987-92), annual data-year end }\end{array}$ \\
\hline all_chg86_92 & $\begin{array}{l}\text { Change in the mortgage delinquency rate (all loans) } \\
\text { (1986:Q4-1992:Q4) }\end{array}$ \\
\hline pci_chg86_92 & $\begin{array}{l}\text { Percent change in real per capita income (2005 \$) } \\
(1986-92) \text {, annual data }\end{array}$ \\
\hline gdp_chg86_92 & $\begin{array}{l}\text { Percent change in nominal gross state product } \\
(1986-92) \text {, annual data }\end{array}$ \\
\hline restrict86 & $\begin{array}{l}\text { Branching Restriction Indicator, } \\
1 \text { (unlimited statewide branching); } \\
2 \text { (limited branching); } \\
3 \text { (branching prohibited) }\end{array}$ \\
\hline
\end{tabular}

FDIC Failed Bank List www.fdic.gov/bank/individual/failed/banklist.html FDIC Failed Bank List; FDIC Summary of Deposits (SOD) www2.fdic.gov/sod/ FDIC SOD

FDIC Historical Statistics on Banking (HSOB) www2.fdic.gov/hsob/ FDIC HSOB; Consolidated Reports of Condition and Income (Call Reports)

Call Reports

Federal Housing Finance Agency

Federal Housing Finance Agency

FDIC Statistics on Depository Institutions (SDI) www2.fdic.gov/SDI/index.asp

Mortgage Bankers Association

Mortgage Bankers Association

Mortgage Bankers Association

Bureau of Labor Statistics

Bureau of Economic Analysis

Bureau of Economic Analysis

Administrative Office of the United States Courts; Bureau of Labor Statistics Quarterly Census of Employment and Wages

Rice and Strahan (2010)

Federal Housing Finance Agency

Federal Housing Finance Agency

FDIC Statistics on Depository Institutions (SDI) www2.fdic.gov/SDI/index.asp $>$

Mortgage Bankers Association

Bureau of Economic Analysis

Bureau of Economic Analysis

Authors' calculations 
